\title{
STRATEGI KONTRUKTIF DAN DEKONSTRUKTIF: PROSES IDENTIFIKASI POLA BILANGAN MAHASISWA CALON GURU SD
}

\author{
Iva Nurmawanti ${ }^{1}$, Radiusman ${ }^{2}$, Linda Feni Haryati $^{3}$, Muhammad Sobri', \\ Ashar Pajarungi Anar 5 \\ 1,2,3,4,5 Fakultas Keguruan dan Ilmu Pendidikan, Universitas Mataram \\ email: ${ }^{1}$ ivanurmawanti@unram.ac.id \\ ${ }^{2}$ radiusman@unram.ac.id \\ 3 lindafeni@unram.ac.id \\ ${ }^{4}$ muhammad.sobri@unram.ac.id \\ 5ashar.pajarungianar@unram.ac.id
}

\begin{abstract}
Abstrak
Tujuan dari penelitian ini untuk mendeskripsikan proses identifikasi mahasiswa calon guru SD dalam menggunakan stategi konstruktif dan dekonstruktif. Subjek penelitian dalam penelitian ini adalah mahasiswa PGSD Universitas Mataram semester 6 yang mengikuti perkuliahan pembelajaran matematika SD. Jenis penelitian ini adalah penelitian deskriptif dengan pendekatan kualitatif. Data yang dikumpulkan berupa hasil tes soal tentang pola dan wawancara. Selanjutnya data tersebut dianalisis. Hasil analisis data menujukkan tidak ada perbedaan antara proses identifikasi pola mahasiswa baik yang menggunakan strategi konstruktif maupun dekontruktif. Proses yang dilakukan mahasiswa yaitu melihat bentuk dari penyusun gambar, membuat aturan pada masing-masing gambar, kemudian menentukan aturan pola selanjutnya berdasarkan aturan yang telah dibuat sebelumnya pada masingmasing gambar.
\end{abstract}

Kata Kunci: identifikasi pola, strategi konstruktif, strategi dekontruktif, pola figural.

\begin{abstract}
This study aims to describe the process of identifying elementary student teacher candidates using constructive and deconstructive strategies. This study's research subjects were 6th-semester PGSD students of Mataram University who attended elementary mathematics learning courses. This type of research is a descriptive study with a qualitative approach. Data collected in the form of test results about patterns and interviews. Then the data is analyzed. The results of the data analysis showed that there was no difference between the process of identifying student patterns using either constructive or deconstructive strategies. The process carried out by students is seeing the shape of the image compiler, making rules for each image, then determining the next pattern rules based on the rules that have been made previously in each image.
\end{abstract}

Keywords: pattern identification, constructive strategy, deconstructive strategy, figural pattern

\section{PENDAHULUAN}

Identifikasi pola merupakan bagian awal dari pembelajaran matematika yang berkaitan erat dengan aljabar. Pola bilangan khususnya pola figural direkomendasikan oleh para ahli sebagai pendekatan untuk pengenalan aljabar, khususnya penalaran aljabar, generalisasi dan pembuaktian (Samson, 2012). Kesuksesan dalam melakukan identifikasi pola dan melakukan generalisasi dapat menentukan kesuksesan dalam materi aljabar. Pentingnya pembejaran tentang pola dalam matematika ditandai dengan dimulainya pembelajaran tentang pola dan generalisasi sejak sekolah SD. Oleh sebab itu, guru SD tentunya harus mampu menguasai materi ini dengan baik agar dapat menentukan kesuksesan dari peserta didik.

Pentingnya pola dalam matematika juga disampaikan Barbosa, dkk (2007) yang menjelaskan bahwa kemampuan penyelesaian masalah, analisis kasus tentang pola, organisasi data secara sistematis, dan generalisasi dapat dikembangkan dengan memberikan tugas 
berkaitan dengan pola. Kemampuan berpikir kreatif dan matematis juga dapat dikembangkan dengan memberikan masalah problem solving tentang pola. (Barbosa, dkk, 2012).

Berdasarkan pentingnya kemampuan menguasai pola bilangan namun masih banyak kesulitan terkait menyelesaikan masasalah pola. Kegagalan pada melakukan generalisasi. Proses generalisasi khususnya pada pola bergambar mengalami kegagalan karena disebabkan cara pandang terhadap bentuk geometri secara umum tanpa melihat struktur gambar pola (Setiawan et al., 2020). Ditingkat mahasiswapun khususnya mahasiswa calon guru SD masih ditemukan kesalah yang dialami. Hal ini berkaitan dengan cara dalam menyelesaikan masalah pola yaitu dengan rumus. Mahasiswa hanya mengingat rumus tanpa menguasai konsep dari rumus tentang pola bilangan. Berikut soal yang diberikan.

Perhatikan gambar deretan dari persegi seperti gambar di bawah!|

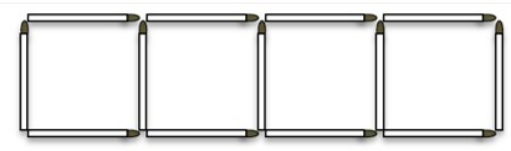

Berdasarkan gambar di atas sebanyak 13 korek api digunakan untuk menyusun 4 persegi. Sekarang jawablah pertanyaan berikut!

1. Berapa banyak korek api yang digunakan untuk membentuk 6 persegi?

2. Berapa banyak korek api yang digunakan untuk membentuk $\mathrm{n}$ persegi?

Gambar 1. Soal pola untuk mahasiswa

Berikut kesalahan yang dilakukan mahasiswa dalam menyelesaikan soal di atas.

$\begin{aligned} U_{1} & =13 \\ U_{2} & =\square \square \square \square=19 \\ a & =13 \quad b=6 \\ U_{n} & =a+(n-1) b \\ & =13+(n-1) 6 \\ & =13+6 n-6 \\ & =6 n+7\end{aligned}$

Gambar 2. Hasil pekerjaan mahasiswa yang salah.

Berdasarkan hasil pekerjaan mahasiswa di atas tentunya dapat diketahui bahwa mahasiswa tidak mampu memahami masalah yang diberikan. Mahasiswa tidak mampu memahami maksud dari U1,U2, U3,... dst dan hubungannya dengan urutan pola keberapa. Sehingga penetapan U1,U2 tidak disesuaikan dengan keterangan susunan persegi yang ingin dibentuk. Penentuan U1,U2 yang salah berpengaruh terhadap penentuan suku pertama dan beda yang akan digunakan pada rumus barisan aritmetika. Oleh sebab itu, mengakibatkan penentuan rumus suku ke-n juga kurang tepat. Proses yang dilakukan ketika mahasiswa hanya meniru suatu prosedur tententu disebut penalaran imitative (Lithner, 2017).

Pemahaman yang salah terkait konsep generalisasi ini tentunya harus segera diselesaikan. Berdasarkan wawancara dengan mahasiswa hal ini terjadi bahwa mereka hanya meniru dari apa yang telah diberikan ketika mereka di jenjang sekolah. Sekolah dan bimbingan belajar hanya menekankan pada rumus semata tanpa menekankan bagaimana memperoleh rumus tersebut. Sementara sebenarnya strategi yang digunakan dalam penyelesaian masalah pola bilangan tidak hanya menggunakan rumus barisan aritmetika. Masalah pola bilangan dapat diselesaikan dengan menggunakan strategi numerik, figural, maupun kombinasi dari keduanya (Rivera, 2018).

Strategi numerik merupakan strategi yang dibangun dari bilangan berdasakan urutan dari pola bilangan, yang kemudian biasanya untuk mempermudah ditabulasikan dalam tabel untuk membangun aturan. Strategi figural berlaku hanya di pola bilangan yang direpresentasikan dalam bentuk gambar dan dibangun dari komponen penyusun gambar berdasarkan isyarat visual 
untuk menentukan aturan pada masing-masing gambar. Adapun kombinasi dari strategi numerik dan figural dibangun dengan melakukan generalisasi berdasarkan isyarat visual dan numerik (Tanişlf \& Õzdaş, 2009).

Selanjutnya dipaparkan oleh Rivera \& Becker (2008) bahwa strategi figural ini memiliki dua tipe yaitu: (1) generalisasi konstruktif, yang terjadi ketika pola figural dipandang sebagai komposisi dari gambar yang tidak tumpang tindih dan merupakan aturan yang dinyatakan langsung sebagai jumlah dari beberapa sub komponen; (2) generalisasi dekonstruktif, yang terjadi ketika pola figural divisualisasikan terdiri dari komponen yang tumpang tindih, dan aturannya dinyatakan secara terpisah dengan menghitung setiap komponen diagram dan kemudian mengurangkan setiap bagian yang tumpang tindih. Berdasarkan penelitian Rivera \& Becker (2008) strategi kontruktif dan dekontruktif dapat membantu mahasiswa untuk sukses menyelesaikan masalah tentang pola. Strategi visual dapat digunakan dalam pembelajaran untuk membantu siswa lebih memahami materi pola khususnya generalisasi (Montenegro et al., 2018).

Berdasarkan kesalahan yang dilakukan mahasiswa akan dibangun pemahaman terkait proses identifikasi pola berdasarkan strategi kontruktif dan dekontruktif. Oleh sebab itu tujuan dari penelitian ini untuk mengetahui bagaimana proses identifikasi pola mahasiswa berdasarkan strategi konstruktif dan dekonstruktif oleh mahasiswa. Deskripsi tentang proses identifikasi tersebut dapat digunakan sebagai bahan pertimbangan tentang apa yang harus dilakukan jika ingin sukses dalam bekerja dengan pola.

\section{METODE PENELITIAN}

Pendekatan kualitatif digunakan dalam penelitian ini. Penelitian kualitatif bertujuan untuk memahami fenomena yang dialami langsung oleh subjek penelitian yang secara holistik dan dideskripsikan dalam bentuk kata, kalimat, dan bahasa terhadap suatu masalah alamiah khusus dengan menggunakan metode ilmiah (Moleong, 2006). Data pada penelitian ini diperoleh dari hasil pekerjaan mahasiswa pada soal pola bilangan khususnya dalam pola figural. Data penelitian juga diperoleh dari hasil wawancara kepada mahasiswa. Selanjutnya data penelitan yang diperoleh dari hasil pekerjaan mahasiswa dan wawancara akan dideskripsikan sebagai hasil dari penelitian ini. Penelitian ini melibatkan 7 mahasiswa PGSD Universitas Mataram. Ketujuh mahasiswa tersebut dipilih karena mereka yang menjawab salah menggunakan rumus deret aritmetika. Selain itu mahasiswa dipilih berdasarkan kemampuan komunikasi yang baik. Hal ini dapat mendukung perolehan data dari hasil wawancara kepada mahasiswa.

\section{HASIL DAN PEMBAHASAN}

Hasil pekerjaan mahasiswa dari soal tentang pola, menunjukkan bahwa dari 6 mahasiswa menggunakan strategi konstruktif, 1 mahasiswa yang menggunakan strategi dekonstruktif. Berikut adalah soal tentang pola yang diberikan kepada mahasiswa.

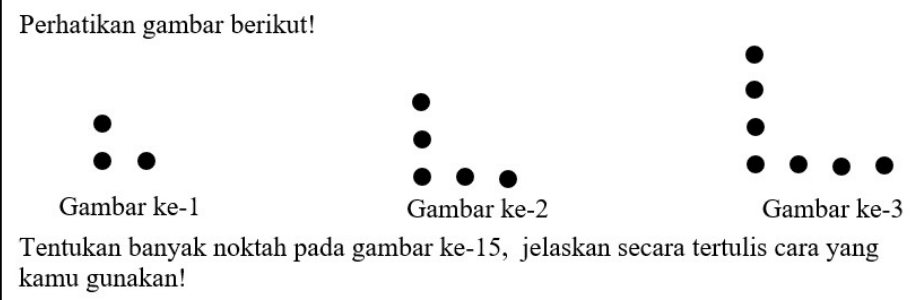

Tentukan banyak noktah pada gambar ke-15, jelaskan secara tertulis cara yang kamu gunakan!

Gambar 3. Soal Pola untuk mahasiswa

Berikut ini adalah beberapa bentuk hasil pekerjaan mahasiswa berdasarkan strategi yang digunakan (konstruktif dan dekonstruktif). Ada 5 strategi konstruktif yang berbeda yang digunakan mahasiswa. Selanjurnya akan dideskripsikan proses identifikasi berdasarkan strategi kontruktif yang digunakan mahasiswa. 


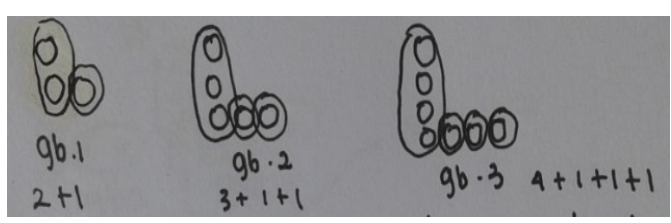

Gambar 4. Hasil pekerjaan mahasiswa A

Berdasarkan hasil pekerjaan mahasiswa di atas, diketahui bahwa mahasiswa melihat adanya struktur gambar yang tidak saling tumpang tindih. Struktur gambar tersebut memiliki dua bagian yang vertikal dan horizontal. Selanjutnya untuk yang vertikal mahasiswa menyesuaikan dengan posisi gambar. Hal ini digunakan mahasiswa untuk mempermudah dalam membuat aturan untuk menentukan banyaknya penyusun gambar selanjutnya. Sekaligus untuk menentukan rumus dari gambar ke-n untuk menentukan banyaknya penyusun gambar ke-15 yaitu $(\mathrm{n}+1)+\mathrm{n}$.

Selanjutnya berikut hasil pekerjaan mahasiswa B yang menggunakan strategi kontruktif.

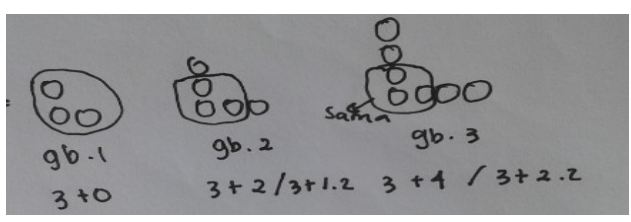

Gambar 5. Hasil pekerjaan mahasiswa B

Berdasarkan hasil pekerjaan mahasiswa tersebut dapat dilihat bahwa mahasiswa tersebut melihat penyusun gambar tidak ada yang saling tumpang tindih. Mahasiswa fokus pada penyusun gambar yang sama. Bagian yang sama itu yaitu 3 titik yang ada di pojok. Melihat adanya hal yang sama pada suatu gambar ini disebut juga sebagai strategi similarity (Nurmawanti, 2016). Selanjutnya berdasarkan struktur gambar yang tidak saling tumpeng tindih dan sama tersebut dibuat aturan pada masing-masing gambar untuk menentukan aturan umun yang akan digunakan dalam menentukan banyak titik pada gambar ke 15. Adapun generalisasi yang ditemukan yaitu $3+2(n-1)$.

Subjek selanjutnya yaitu mahasiswa $\mathrm{C}$ dan berikut hasil pekerjaan mahasiswa $\mathrm{C}$.

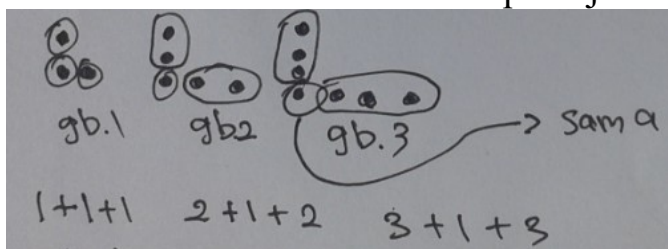

Gambar 6. Hasil pekerjaan mahsiswa C.

Berdasarkan hasil pekerjaan mahasiswa $\mathrm{C}$ dapat dilihat bahwa mahasiswa melihat adanya kesamaan penyusun gambar yaitu satu titik di bagian pojok. Mahasiswa melihat gambar tidak ada yang saling tumpeng tindih. Selanjutnya ada penyusun lain yang secara vertikal maupun horizontal. Banyaknya penyusun gambar yang vertikal maupun horizontal ini memiliki banyak titik yang sama. Berdasarkan hasil identifikasi ini selanjutnya melalui wawancara dan scaffolding mahasiswa membuat aturan pada masing-masing gambar untuk menentukan aturan umum yaitu $\mathrm{n}+1+\mathrm{n}$.

Untuk hasil pekerjaan mahasiswa $\mathrm{D}$ dapat dilihat pada gambar berikut ini.

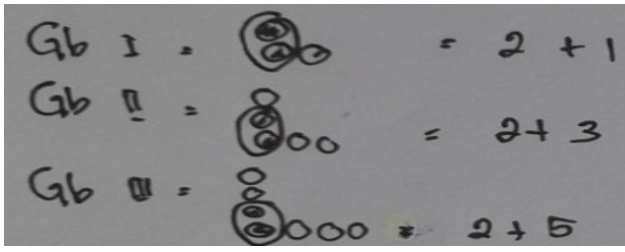

Gambar 7. Hasil pekerjaan mahasiswa D 
Mahasiswa D melakukan cara yang sama dengan mahasiswa B yaitu melihat adanya penyusun gambar yang sama pada masing-masing pola. Melihat kesamaan dari penyusun gambar merupakan bagian dari proses identifikasi pola (Hourigan \& Leavy, 2015). Selanjutnya gambar tersebut dilihat juga tidak ada yang saling tumpang tindih. Selanjutnya berdasarkan kesamaan tersebut dibuatlah aturan pada masing-masing gambar untuk ditemukan aturan umumnya. Berdasarkan wawancara dan scaffolding yang dilakukan kepada mahasiswa, umum yang ditemukan mahasiswa yaitu $2+2 \mathrm{n}-1$. Selanjutnya aturan ini digunakan mahasiswa untuk menentukan banyak titik pada gambar ke- 15 .

Selanjutnya berikut proses identifikasi pola berdasarkan strategi kontruktif yang digunakan oleh mahasiswa E.

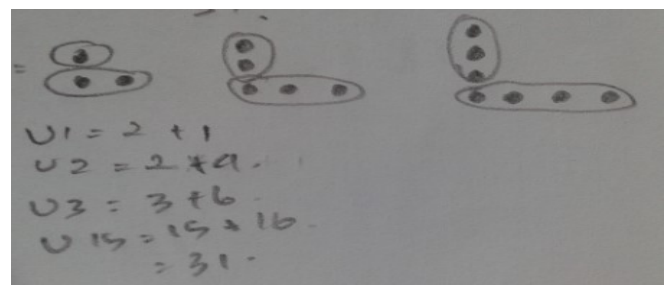

Gambar 8. Hasil pekerjaan mahasiswa E

Berdasarkan hasil pekerjaan mahasiswa tersebut dengan menggunakan strategi kontruktif secara tidak langsung mahasiswa E sudah dapat melakukan generalisasi. Berdasarkan hasil wawancara dari bagaimana mahasiswa melihat gambar yang tidak saling tumpeng tindi seperti pada gambar di atas. Kemudian ia membuat aturan pada masing-masing gambar berdasarkan apa yang dilihatnya tersebut. Selanjutnya berdasarkan aturan tersebut digunakannya untuk menentukan aturan umumnya yang secara tidak langsung atau tidak tertulis digunakan untuk menentukan banyak titik pada gambar ke-15. Mahasiswa menjelaskan bahwa "Yang atas sesuai dengan posisi gambar dan yang bawah posisi gambar di tambah 1". Jadi secara tidak langsung dia dapat membuat aturan $n+n+1$

Selanjutnya berikut hasil pekerjaan mahasiswa F.

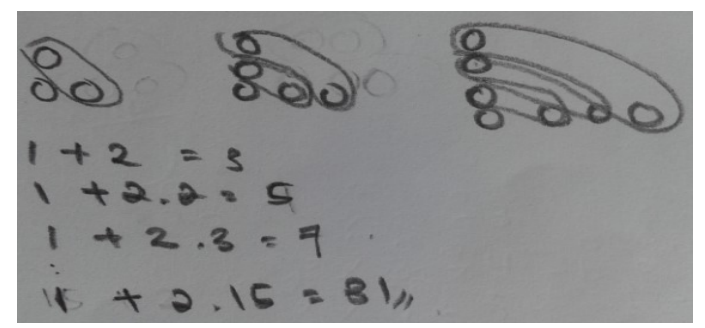

Gambar 9. Hasil pekerjaan mahasiswa F

Mahasiswa $\mathrm{F}$ juga melihat gambar tidak ada yang saling tumpeng tindih. Dia melihat gambar disusun menyamping. Dan susunan yang menyamping memiliki banyak titik yang sama yaitu 2 sebanyak posisi gambar. Sehingga hal ini yang digunakan mahasiswa untuk menentukan gambar ke-15. Secara tidak langsung mahasiswa $\mathrm{F}$ juga mampu membuat generalisasi untuk menentukan banyak titik pada gambar ke-15. Aturan yang secara umum dibuat mahasiswa $\mathrm{F}$ yaitu $1+2 \mathrm{n}$.

Selanjutnya hanya satu mahasiwa yang menggunakan strategi dekontruktif.

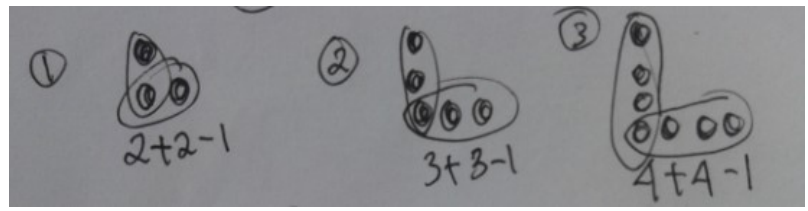

Gambar 10. Hasil pekerjaan mahasiswa G 
Proses identifikasi yang dilakukan mahasiswa $G$ di atas yang menggunakan strategi dekontruktif dilakukan dengan melihat komponen yang tumpang tindih pada masing-masing gambar yang ada, dan selanjutnya membuat aturan yang terpisah dari masing-masing gambar. Aturan yang dibuat mahasiswa tersebut selalu ada pengurangan kuantitas yang saling tumpang tindih pada masing-masing gambar. Hal yang sama pada mahasiswa yang menggunakan strategi konstruktif digunakan oleh mahasiswa yang menggunakan strategi dekontruktif. Aturanaturan yang dibuat mahasiswa pada gambar ke-1, ke-2 dan ke-3 diidentifikasi persamaan dan perbedaannya dan digunakan untuk menentukan banyaknya penyusun gambar ke-15.

Berdasarkan pekerjaan mahasiswa di atas mereka mampu mengerjakan atau menentukan aturan generalisasi pola melalui strategi kontruktif dan dekontruktif. Mereka juga mampu memahami bagaimana hubungan fungsional yang terjadi antara posisi gambar dengan penentuan aturan pada masing-masing gambar. Hal ini berkaitan dengan proses berikir aljabar mahasiswa. Proses berpikir aljabar untuk menentukan aturan umum pada generalisasi pola harus melalui atau memahami hubungan fungsional yang terjadi pada pola bilangan (Nurmawanti \& Sulandra, 2020).

\section{KESIMPULAN}

Proses identifikasi yang dilakukan mahasiswa berdasarkan strategi konstruktif dan dekontruktif ada yang berbeda dan ada yang sama.

a. Proses identifikasi pada mahasiswa yang menggunakan strategi konstruktif dan dekotruktif ada yang sama yaitu melihat susunan gambar pada gambar ke-1, ke-2, dan ke-3 sama. Sehingga aturan dari masing-masing gambar juga sama. Aturan yang digunakan untuk menentuka gambar ke-15 juga disesuaikan dengan aturan yang dibuat pada gambar ke-1, ke-2, dan ke-3.

b. Proses identifikasi yang berbeda dilakukan oleh mahasiswa yang menggunakan strategi konstruktif yaitu dengan melihal komponen penyusun gambar yang berbeda pada gambar ke-1, ke-2, dan ke-3. Namun aturan yang dibuat pada gambar ke-1, ke-2, dan ke-3 sama. Sehingga dia dapat menentukan banyaknya penyusun gambar pada pola selanjutnya.

Secara umum proses identifikasi pola yang dilakukan mahasiswa baik secara kontruktif maupun dekontruktif sama. Proses yang dilakukan mahasiswa untuk membuat generalisasi yaitu melihat bentuk dari penyusun gambar, membuat aturan pada masing-masing gambar, kemudian menentukan aturan pola selanjutnya berdasarkan aturan yang telah dibuat sebelumnya pada masing-masing gambar..

\section{REFERENSI}

Barbosa, dkk. (2007). The influence of visual strategies in generalization: a study with 6th grade students solving a pattern task. Proceedings of the Fifth Congress of the European Society for Research in Mathematics Education, 2007, pp. 844-851

Barbosa, dkk. (2012). Pattern Problem Solving Tasks As A Mean To Foster Creativity In Mathematics. Proceedings of the 36th Conference of the International Group for the Psychology of Mathematics Education, Vol. 4, 171-178. Taipei, Taiwan: PME.

Hourigan, A., \& Leavy, A. (2015). What' s the Rule? APMC, 20(4), 31-39.

Lithner, J. (2017). Principles for designing mathematical tasks that enhance imitative and creative reasoning. ZDM - Mathematics Education, 49(6), 937-949. https://doi.org/10.1007/s11858-017-0867-3

Moleong, L. J. (2006). Metode Penelitian Kualitatif. Bandung: Remaja Rosda. 
Montenegro, P., Costa, C., \& Lopes, B. (2018). Transformations in the Visual Representation of a Figural Pattern. Mathematical Thinking and Learning, 20(2), 91-107. https://doi.org/10.1080/10986065.2018.1441599

Nurmawanti, Iva; Bambang, E.I; Sulandra, M. I. (2016). Identifikasi Pola Siswa SMP Berdasarkan Teori Gestalt. Jurnal Pembelajan Matematika, III(2), 154 - 161.

Nurmawanti, I., \& Sulandra, I. M. (2020). Exploring o f Student' s Algebraic Thinking Process Through Pattern Generalization using Similarity or Proximity Perception. 9, 191-202.

Rivera, F. D. (2018). Pattern generalization processing of elementary students: Cognitive factors affecting the development of exact mathematical structures. Eurasia Journal of Mathematics, Science and Technology Education, 14(9). https://doi.org/10.29333/ejmste/92554

Rivera, F. D., \& Becker, J. R. (2008). Middle school children's cognitive perceptions of constructive and deconstructive generalizations involving linear figural patterns. ZDM International Journal on Mathematics Education, 40(1), 65-82. https://doi.org/10.1007/s11858-007-0062-z

Samson, D. (2012). Pictorial pattern generalisation: Tension between local and global visualisation. Pythagoras, 33(3), 1-9. https://doi.org/10.4102/pythagoras.v33i3.172

Setiawan, Y. E., Purwanto, Parta, I. N., \& Sisworo. (2020). Generalization strategy of linear patterns from field-dependent cognitive style. Journal on Mathematics Education, 11(1), 77-94. https://doi.org/10.22342/jme.11.1.9134.77-94

Tanişlf, D., \& Õzdaş, A. (2009). The strategies of using the generalizing patterns of the primary school 5th grade students. Kuram ve Uygulamada Egitim Bilimleri, 9(3), 1485-1497. 